\title{
Modified Legal Framework and Opening of the Liner Shipping Market in the Republic of Croatia to Shipping Companies from the European Economic Area
}

\section{Nikola Mandić}

Generally speaking, public transport is the transport of persons and cargo available for use to the general public, performed on the basis of a transport contract. Public transport costal liner shipping is the transport of passengers, cargo and vehicles in the internal marine waters and territorial sea of the Republic of Croatia performed on pre-established lines in compliance with the published terms and conditions of the sailing schedule and services pricelist. The Act on Transport in Liner Shipping and Occasional Costal Maritime Transport established the public transport system in the Republic of Croatia, ensuring regular connection of inhabited islands with the mainland and other inhabited islands, as well as between coastal towns, with an appropriate number of daily two-way connections, to improve the conditions of island life and stimulate their development. Prior to the accession of the Republic of Croatia to the European Union, the maritime liner shipping market in the Republic of Croatia was reserved primarily for Croatian shipping companies. Now, following the expiry of the transitional period negotiated in pre-accession negotiations with the European Union and the expiry of previously concluded concession contracts, the market is opening up to shipping companies from the European Economic Area. Hence, over the last couple of years, the Republic of Croatia was required to modify its legal framework regulating this subject matter. This paper presents novelties in the legal framework introduced in 2016 and 2017, which directly affect the opening of the maritime liner shipping market in the Republic of Croatia to shipping companies from the European Economic Area, with the critical analysis of the new solutions.

University of Split, Faculty of Maritime Studies, Split, Croatia

e-mail: nmandic@pfst.hr

doi: 10.7225/toms.v06.n02.006

This work is licensed under (cc) BY

\section{KEY WORDS}

$\sim$ Legal framework

$\sim$ Public transport in costal liner shipping

$\sim$ Contracts on public transport services

$\sim$ Concession contracts

$\sim$ Sailing schedule

$\sim$ Public liner shipping without public service obligation

\section{INTRODUCTION}

The accession of the Republic of Croatia to the European Union on 1 July 2013 marked the beginning of the application of new rules in the performance of maritime cabotage in the Republic of Croatia. While prior to the accession of the Republic of Croatia to the European Union, exclusively national shipping companies had the right to perform the transport of passengers and cargo between Croatian ports (maritime cabotage), the maritime cabotage market has since been opened to all shipping companies from the European Economic Area. The EU maritime cabotage market has been liberalized with the Regulation (EEC) No. 3577/92 applying the principle of freedom to provide services to maritime transport within Member States (maritime cabotage) allowing all shipping companies having business establishment in any EU member state, i.e. in the European Economic Area to perform maritime cabotage across the European Union. Inter alia, maritime cabotage rules also apply to the performance of public transport in coastal liner shipping. In pre-accession negotiations with the European Union, the Republic of Croatia negotiated a transitional period for public transport contracts in coastal liner shipping predating the accession of the Republic of Croatia to the European Union, with their validity limited to 31 December 2016, due to which the market on the shipping lines which were the subject of such contracts remained closed 
to European shipping companies until the expiry of the said transitional period. Consequently, a comprehensive process of granting concessions for the performance of public transport in costal liner shipping was conducted immediately prior to the accession of the Republic of Croatia to the European Union. Concession contracts for 24 ferry, 15 high-speed and 8 shipping lines were executed. ' In spite of the transitional period envisaged by the Treaty Concerning the Accession of the Republic of Croatia to the European Union, due to the political instability in the Republic of Croatia and slow pace of work in the ministry competent for maritime affairs, in 2016, the Republic of Croatia reached an agreement with the European Commission to extend the validity of all contracts concluded prior to 1 July 2013 by one year, i.e. by 31 December 2017 at the latest. Hence annexes to contracts for transport on lines were concluded with all shipping companies which serviced the lines at the time, with validity period until the selection of a new shipping company, but no later than by the end of 2017.

The period was used to prepare the legal framework for future EU market competition as efficiently as possible.

In the Republic of Croatia, there are a total of 52 state lines on which public transport services in coastal liner shipping are provided by 13 Croatian shipping companies with the combined fleet of over 70 ships. Only eight state lines are profitable ${ }^{2}$ on which shipping companies pay compensation under their concession contracts. On other, unprofitable lines, shipping companies providing public transport services are granted public service compensations. The new Decision on the establishment of state lines in public transport in coastal liner shipping adopted by the Government of the Republic of Croatia on 22 December 2016, increased both the capacity and frequency of state lines. The Decision establish a total of 53 state lines. ${ }^{3}$

Preparatory actions and the procedure for the allocation of the right to provide public transport services in coastal liner shipping to shipping companies are performed by the Coastal Liner Services Agency (hereinafter referred to as the Agency). The Agency is currently publishing invitations to tender, i.e. carrying out tender procedures for the selection of shipping companies on 48 state lines, using the e-procurement module of the Electronic Public Procurement Classifieds of the Republic of Croatia. Since the tender procedures are open to all interested shipping companies

1. The previously signed two contracts on shipping lines and a subsequently executed contract on one ferry line and two shipping lines, ensured the full engagement of all capacities of Croatian shipping companies in the provision of public transport services in costal liner shipping on 52 state lines.

2. According to data published by the Coastal Liner Services Agency, there are a total of eight profitable state lines - seven ferry (Valbiska - Merag and back; Porozina - Brestova and back; Prizna - Žigljen and back; Mišnjak - Stinica and back; Supetar - Split and back; Dominče - Orebić and back; Stari Grad - Split and back) and one shipping line (Trogir - Slatine - Split and back).

3. See more in infra 4. Decision on the establishment of state lines in public transport in costal liner shipping. from the European Economic Area, invitations to tender and notices on intention to grant concession are published both in the Electronic Public Procurement Classifieds of the Republic of Croatia and in the supplement to the Official Journal of the European Union - Tenders electronic daily (TED). The critical preconditions for the implementation of the above procedures are the compilation of schemes for granting state aid in the form of public service compensation on state lines and conducting concession feasibility studies.

\section{LEGAL SOURCES}

Legal sources regulating public transport in coastal liner shipping may be divided into three basic groups - legal sources, sublegal sources and European legal sources.

Legal sources:

1. Maritime Code 4 ,

2. Act on Transport in Liner Shipping and Occasional Coastal Maritime Traffic ${ }^{5}$,

Sublegal sources:

1. Regulation on the conditions and evaluation of criteria for granting concessions and awarding contracts for the provision of the public services of public transport in costal liner shipping ${ }^{6}$,

2. Ordinance on requirements to be met by the ship and the shipping company to perform public transport services in costal liner shipping ${ }^{7}$,

3. Ordinance on requirements to be met by the ship and the shipping company to perform international maritime liner transport services $^{8}$,

4. Ordinance on the conditions and manner of realization of the right to privileged transport on public maritime transport lines ${ }^{9}$,

5. Decision on the amount of discount on regular passenger ticket prices in the privileged transport of persons and vehicles in public coastal liner maritime transport ${ }^{10}$,

6. Decision on the establishment of state lines in public transport in costal liner shipping ${ }^{11}$,

7. Ordinance on the conditions for the performance of maritime cabotage in the Republic of Croatia ${ }^{12}$.

European legal sources:

1. Regulation (EU) No. $1177 / 2010$ concerning the rights of passengers when travelling by sea and inland waterway and amending Regulation (EC) No. 2006/2004,

4. Official Gazette no. 181/04, 76/07, 146/08, 61/11, 56/13 and 26/15

5. Official Gazette no. 33/06, 38/09, 87/09, 18/11, 80/13 and 56/16.

6. Official Gazette no. 31/14.

7. Official Gazette no. $26 / 14$.

8. Official Gazette no. $130 / 06$ and $83 / 13$

9. Official Gazette no. $41 / 17$

10. Class: 011-01/13-05/15, reg. no.: 530-03-2-2-2-14-10, 25 March 2014

11. Class: 022-03/16-04/363, , reg. No.: 50301-25/14-16-2, 22 December 2016

12. Official Gazette no. 56/14 and 56/17. 
2. Council Regulation (EEC) No. $3577 / 92$ applying the principle of freedom to provide services in maritime transport within Member States (maritime cabotage).

In 2016 and 2017, Act on Transport in Liner Shipping and Occasional Coastal Maritime Traffic and Ordinance on the conditions for the performance of maritime cabotage in the Republic of Croatia were amended, and the new Ordinance on the conditions and manner of realization of the right to privileged transport on public maritime transport lines and Decision on the establishment of state lines in public transport in costal liner shipping adopted.

\section{ACT ON TRANSPORT IN LINER SHIPPING AND OCCASIONAL COASTAL MARITIME TRAFFIC}

The activity of provision of public transport services in liner shipping and occasional maritime transport in the Republic of Croatia is regulated by the Act on Transport in Liner Shipping and Occasional Coastal Maritime Traffic (hereinafter: Act). The Act ensures regular traffic connection of inhabited islands with the mainland and other inhabited islands, with an appropriate number of daily two-way connections, intending to meet the needs of islanders, improve living conditions on the islands and stimulate their development. The Act was adopted at the session of the Croatian Parliament held on 10 March 2006, and entered into force on 1 April 2006..$^{13}$ It was amended on several occasions, in 2006, 2009, 2011, 2013 and 2016. The 2016 amendments to the Act entered into force on 25 June 2016.

The Act consists of a total of 70 articles divided into seven chapters: General Provisions, Public Transport, Occasional Transport, Administrative Supervision and Inspection, Violations, Penalty Provisions, Transitional and Final Provisions. The Act stipulates that transport services on lines on which regular public transport is performed (state lines, county, inter-county and local lines) are services of general economic interest with public service obligation. The Act ensures the implementation of all EU enactments regulating the subject-matter and served as the basis for the adoption of several more detailed sublegal regulations. ${ }^{14}$

In 2006, based on the Act, the Government of the Republic of Croatia founded the Agency as the main regulatory body in the Republic of Croatia for the subject matter of liner passenger transport in the Adriatic. The Agency grants rights to provide public transport services in costal liner shipping, sets up the public transport IT system and regulates the realization of the

13. On the date of entry of the Act into force, the following became null and void: Act on public transport in costal liner shipping (Official Gazette no. 131/97), Articles 3-6 and Article 19 of the Act on Jadrolinija, Rijeka (Official Gazette no. 11/96), Article 10, paragraph 3, Article 10, paragraphs 1, 2, 4 and 6 in the part relating to maritime transport, Article 12, paragraphs $1-5$, Article 12, paragraph 6 . of the Act on Islands in the part relating to maritime transport (Official Gazette no. 34/99 and 32/02).

14. Fore more details see supra 1. Legal sources. right to privileged transportation. Bodies of the Agency are the Governing Council and the Director.

\subsection{The 2016 Amendments to the Act on Transport in Liner Shipping and Occasional Coastal Maritime Traffic}

In the 2016 amendments to the Act, many articles were modified to accommodate for the terminological harmonization of the text. Terminological adjustments may be said to have been belated, since they should have been made in the 2013 amendments to the Act. The new terms in the Act ensure the full implementation of the package of measures envisaged by the European rules on state aid for services of general economic interest (SGEI package). Following interventions into its content, the Act could neither be followed nor understood without having the new terms defined.

State, county, intercounty and local lines are defined as lines on which public coastal liner shipping services are provided with public service obligation, which is a novelty in the Act. Moreover, as to the content of the Decision on the establishment of state lines, adopted by the Government of the Republic of Croatia at the proposal of the ministry competent for maritime affairs, it is stipulated, inter alia, that the decision must state ship type and minimum capacity. The imprecision of the wording ship type and capacity contained in the previous version of the Act was remedied exactly by emphasizing that it needed to indicate the minimum capacity of ships.

With respect to terminological modifications of the Act, the term aid is replaced with the term public service compensation and the term concession with the term public service contract. According to its legal definition, public service compensation is aid granted by the public authority to the shipping companies providing public transport services on lines of general economic interest and with public service obligation, on which revenue generated by service provision is insufficient to cover the costs relating to the fulfilment of the public service obligation (nonprofitable lines). A public service contract is a contract between the concession-granting authority / contracting authority and a shipping company regulating the provision of a service, concluded in the form of a concession contract for the provision of public transport services or contract on public transport services. Concession contract for the provision of public transport services is a contract equivalent to the contract on public services for activities of public transport, stipulating that the selected concessionaire is obligated to pay a concession compensation pursuant to the Concession Act. Contract on public transport services is a public procurement contract the subject of which are waterway transport services, concluded in accordance with the Public Procurement Act. Furthermore, the term classic shipping line is replaced with the term shipping line, i.e. the word classic 
was deleted as redundant since that ship category no longer exists.

The amendments to the Act likewise expanded the activities of the Agency. These are defined in accordance with Regulation (EU) No. 1177/2010, which separately specifies Agency activities considered to be public powers. The right to be awarded a concession is replaced with the new term granting of the right to provide public transport services and the scope of Agency activities is broadened to include the setting-up of the public transport IT system and activities pertaining to the realization of the right to privileged transport. In addition, yet another novelty in the Act is Agency obligation to submit a report on its activities to the Government of the Republic of Croatia on an annual basis, by late April of the current year for the previous year, due to the lack of such a provision being identified as a shortcoming of the then applicable text of the Act. The activities of the Agency have also been expanded. Apart from terminological changes and adjustment of Agency activities in compliance with the amendments to the Act, granting of approvals for the provision of public transport services without public service obligation is also indicated as an Agency activity.

Changes to the tasks and activities of the Agency were accompanied by the corresponding modifications of the duties of the Agency's Governing Council. However, these amendments to the Act failed to rectify the poor solution regarding the composition of the Governing Council, introduced into the Act with the 2013 amendments. Namely, the said amendments proscribe a change in the composition of the Governing Council, reducing its membership from the then current seven to five members. The currently applicable provision stipulates that only and exclusively representatives of ministries may be appointed (three from maritime, one from finance and one from island development), which is considered a poor legal solution since it increases the concentration of political power. The Croatian Chamber of Commerce, the Croatian Register of Shipping, shipping company associations and the Seafarers' Union of Croatia all lost their representatives in the Agency's Governing Council. The non-participation of the shipping company associations and the Seafarers' Union of Croatia in the Agency's Governing Council is partly justified since due to the opening of the market to shipping companies from the European Economic Area, Croatian shipping companies and the Seafarers' Union of Croatia having a say in the decision-making process would hardly contribute to the fair market competition of European and Croatian shipping companies. However, the Croatian Chamber of Commerce and the Croatian Register of Shipping should most certainly be represented in the Agency's Governing Council.

The part of the Act which, in the previously applicable text, regulated concessions, is now titled the right to perform public transport services of general economic interest, which right stems from the entrustment documents establishing public service obligations, namely the concession decision and the decision on the selection of the successful tenderer. That part of the Act was correspondingly modified to account for the said change. As stated previously, the right to perform public transport services of general economic interest is obtained on the basis of the enforceable decision to grant a concession for profitable lines, i.e. decision on the selection of the successful tenderer for non-profitable lines, as entrustment documents lending the shipping companies-service providers authority and establishing their public service obligations. Concession contract is concluded on the basis of enforceable decision to grant a concession, while contract on public transport services is concluded on the basis of the decision on the selection of the successful tenderer. Concession compensation (payment made by the shipping company based on the concession contract for the performance of public transport in coastal liner shipping) is paid for the provision of public transport services. When revenue from service provision realized on a line of general economic interest is insufficient to cover the costs of the fulfilment of the public service obligation, public service compensation is granted.

The proscribed requirements to be met by a shipping company to obtain the right to provide public transport services in coastal liner shipping were modified in 2013 and 2016 due to the need to harmonize them with the EU Acquis. The right to provide public transport services with public service obligation may be granted to a shipping company from the European Economic Area in accordance with Regulation (EEC) No. 3577/92, providing the crew must speak the language proscribed by the regulations on cabotage in the Republic of Croatia, i.e. crew members charged with ensuring passenger safety must understand and give orders and instructions and submit reports in Croatian.

A provision regulating the issue of the need for increased transport capacity was introduced into the Act. Namely, if the Agency determines that there is a real need to increase transport capacities on a line on which regular public transport is performed or any part thereof, it will send the shipping company which was awarded the public service contract, a request to meet the need for increased capacity. If the shipping company is unable to meet the request, the Agency may give its consent for the performance of such transport to another shipping company and pay that company compensation in accordance with the provisions applicable to public liner shipping without public service obligation. This legal solution is compliant with the Regulation (EEC) No. 3577/92 envisaging continuous adjustment of transport connections to new situations, i.e. to the actual needs, primarily through the conclusion of public service contracts. The previous legal solution approached the need for increased transport capacity on public transport lines quite differently. Namely, the previous legal solution stipulated that if the transport volume increased by $30 \%$ in the preceding period no shorter than one 
year, and the concessionaire was unable to accommodate for such increase with his current capacities, another concession could be granted on the same line. Since this legal solution proved to be defective, the 2016 amendments to the Act made a positive breakthrough in the regulation of this issue.

Privileged transport and public passenger transport IT system provisions have also been modified with the latest amendments to the Act. Privileged transport includes discount transport of passengers and vehicles and free transport. The provisions on the privileged transport of islanders and their vehicles are now legally elaborated much more clearly. The Act provides for the funds for privileged discount transport to be provided from the state budget of the Republic of Croatia, from allocations of the competent central state administration bodies. In case of free transportation, funds are compensated to the shipping companies in the framework of compensation for the fulfilment of public service obligation (SGEI package), and for emergency interventions in accordance with regulations on the protection against natural disasters and catastrophes. The technical requirements for the realization of the right to privileged transport are the establishment of an IT system and issuance of island passes for passengers and vehicles and vehicle vignette. The manner and procedure of the realization of the right to privileged transport are proscribed by a separate ordinance brought by the minister competent for maritime affairs, with the prior approval of the minister competent for finances and minister competent for island development. ${ }^{15}$

Pursuant to amendments to the Act, the highest price of service on each line is determined in the tender documentation. Following the adoption of the decision on the selection of the successful tenderer, the concession-granting authority, i.e. contracting authority is considered to have consented to the pricelist of the tenderer, which may be applied as of the date of entry into force of the awarded contract. According to the previous legal solution, the concession-granting authority determined the highest price of public transport services on a given line in the notification on its intent to grant the concession, with the shipping company granted the concession for the performance of public transport on that line determining the pricelist of services.

The Act also changed its regulation of the adoption of sailing schedules. It stipulates that proposed sailing schedules on state lines require the prior approval of the executive body of local selfgoverning units, the competent harbor master's office and the competent port authority, while the Agency gives subsequent approval, following the obtainment of prior approvals. Pursuant to the amendments to the Act from 2013, sailing schedules

15. For more information see infra 3. Ordinance on the conditions and manner of realization of the right to privileged transport on public maritime transport lines. were adopted by the Agency, which likewise approved their change. Since such provision, which failed to specify the sailing schedule adoption procedure, created problems in practice, its modification is a positive novelty introduced by the Act.

As a novelty, the provisions on public liner shipper without public service obligation, which regulate seasonal transport, were included in the Act. Prior to the 2016 amendments to the Act, seasonal transport was considered a part of occasional transport, while it is now regulated separately, as public liner shipping without public service obligation. This transport type is not considered regular public transport, i.e. such lines are not lines with public service obligation, but transport services on such lines are provided according to market principles. The shipping company is required to obtain prior approval of the concessiongranting authority/contracting authority competent for the line's route, i.e. the certificate that such transport does not cover over $80 \%$ of the ports of call on any existent line on which regular public transport with public service obligation is performed. The concession-granting authority/contracting authority will, in each individual case, take into account all circumstances when issuing the approval, especially the effect of the performance of transport on the line without public service obligation to the line on which regular public transport with public service obligation is performed.

The 2016 amendments to the Act also modified the provisions on occasional transport. Such transport is now elaborated in more detail. The occasional transport of passengers in coastal maritime transport is transportation which is not performed on the basis of established sailing schedules and is not considered public liner transport. Occasional transport of passengers must not contain elements of public liner transport. It is intended to cater for the need for one-time transport and does not have the function of transport of daily migration. The occasional transport of passengers especially includes transport as a constituent part of the tourist offer (excursions, package arrangements, passenger transfer), taxi transport and transport of the employees of legal and physical persons for their own needs.

Since a shortcoming was identified in the supervision of the enforcement of the Act, the inspection provisions were supplemented with the provisions on administrative supervision of the Agency's work, to be performed by the ministry competent for maritime affairs. With respect to inspection, new provisions were added which specify in more detail who performs the inspection and introduce measures at the disposal of the inspector.

The transitional and final provisions of the Act of 2016 stipulate that the minister competent for maritime affairs shall, within nine months from the date of entry into force of amendments to the Act, adopt the new Ordinance on the manner of recording of issued tickets of public transport beneficiaries who 
are not beneficiaries of privileged transport. In spite of the expiry of the envisaged period, the Ordinance has yet to be adopted. The Act also proscribes the obligation of the minister competent for maritime affairs to harmonize the Ordinance on the manner and procedure of realization of the right to privileged transport within nine months from the date of entry into force of amendments to the Act. A new Ordinance on the conditions and manner of the realization of the right to privileged transport on public maritime transport lines ${ }^{16}$ was adopted with a slight delay. Finally, the Act proscribes the obligation of the Government of the Republic of Croatia to harmonize the Regulation on the manner of granting concessions and awarding contracts for the provision of the public services of public transport with public service obligation, evaluation of criteria for granting concessions and awarding public service contracts, criteria for establishing the price of services and public service compensation, amount and manner of payment of concession compensations, types and value of tendering security and other issues relating to concession granting and conclusion of public service contracts within that same period. This Regulation is still not harmonized, in spite of the envisaged period having elapsed. The failure to adopt, i.e. harmonize sublegal acts on time introduces a certain level of legal insecurity which should be avoided, especially since the market is being opened up to European shipping companies. The competent ministry is thus recommended to adopt the new/harmonize the existent implementing regulation as soon as possible, to establish a comprehensive legal system regulating this subject matter.

\section{ORDINANCE ON THE CONDITIONS AND MANNER OF REALIZATION OF THE RIGHT TO PRIVILEGED TRANSPORT ON PUBLIC MARITIME TRANSPORT LINES}

On 6 April 2017, the minister competent for maritime affairs adopted the new Ordinance on the conditions and manner of realization of the right to privileged transport on public maritime transport lines on the basis of the Act, which entered into force on 5 May 2017. Upon entry into force of the Ordinance the Ordinance on the conditions and manner of realization of the right to privileged transport on public maritime transport lines ${ }^{17}$ became null and void. The new Ordinance stipulates the conditions and manner of the realization of the right to privileged transport on public maritime transport lines with public service obligation, the amount of the discount applicable to the realization of the right to privileged transport in coastal maritime liner transport with discount and the types of documents issued to the beneficiaries of the right to privileged transport.

The separate parts of the Ordinance regulate: the beneficiaries of the right to privileged transport; transport with

16. Official Gazette no. $41 / 17$

17. Official Gazette no. $1 / 14,52 / 15$ and 56/15. a discount (amount of the discount, transport of passengers with a discount, transport of vehicles at a discount and transport of public services with a discount); free transport (free transport of pupils and students, free transport of children, free transport of pensioners and persons over 65 years of age and free transport of public services); island passes (island passes for passengers and island passes for vehicles); IT system; privileged transport reports; inspection; transitional and final provisions.

As previously stated, privileged transport in coastal liner shipping includes discount transport and free transport. Hence special categories of beneficiaries of the right to discount transport and beneficiaries of the right to free transport have also been identified..$^{18} \mathrm{~A} 50 \%$ discount on regular seasonal ticket prices, determined by the concession-granting authority/contracting authority, is granted in case of discount transport. Island passes are issued to the beneficiaries to enable them to realize their right to privileged transport, with the shipping company being obligated to register issued tickets by indicating the respective line, date of trip, price and island pass number, for every trip realized. The Agency set up the Information system for registering islander rights (SEOP) to keep track of the beneficiaries of the right to privileged transport, grant rights to privileged transport and monitor the realization of such rights. The SEOP system allows the keeping of records, codebooks and data catalogues necessary for the administration of the privileged transport system. Shipping companies performing public maritime liner transport on state lines are obligated to continuously and immediately enter all data on transported beneficiaries of the right to privileged transport into SEOP, to allow the Agency to compile monthly reports on the basis thereof.

\section{DECISION ON THE ESTABLISHMENT OF STATE LINES IN PUBLIC TRANSPORT IN COASTAL LINER SHIPPING}

Minimum transport frequency, ship type and minimum capacity, as well as the type of transport on state lines in public transport in coastal liner shipping are all proscribed by the Decision on the establishment of state lines in public transport in coastal liner shipping. State lines are established by the Government of the Republic of Croatia at the proposal of the ministry competent for maritime affairs. The Decision may only be amended if such change is rendered necessary due to economic interests, i.e. the adjustment of public transport in coastal liner shipping to the newly emerging needs.

In accordance with Article 7, paragraph 1 of the Act, the Government of the Republic of Croatia adopted the new Decision on the establishment of state lines in public transport in coastal

18. For more information see Article 2 of the Ordinance on the conditions and manner of realization of the right to privileged transport on public maritime transport lines. 
liner shipping ${ }^{19}$ on 22 December 2016, establishing state ferry, high-speed and shipping lines, and proscribing appropriate ship type and minimum capacity, route and minimum frequency of weekly return trips. The Decision established a total of 53 state lines, out of which 25 ferry, 15 high-speed and 13 shipping lines. The first novelty is the reduction of the number of state lines, from 56 stipulated in the previous Decision. The second novelty are increased ship capacities and trip frequency on certain state lines. The third novelty is that the so called coastal ferry line (Rijeka - Split - Stari Grad - Korčula - (Sobra) - Dubrovnik and back) was once again identified as a year-round line with increased vehicle and passenger capacity. Namely, the coastal ferry line was gradually being extinguished. It was first cancelled during low season in 2010, followed by the reduction in the minimum passenger and vehicle capacity, with the option of deploying a smaller ferry in 2013 and the final abandonment of the line by the state shipping company in 2014. The preconditions for the full revival of this line with a long tradition have now been fulfilled.

\section{CONCLUSION}

The 2016 amendments to the Act modify a certain number of articles and introduce some terminological changes. With the adoption of these amendments, this subject-matter became fully harmonized with the EU Acquis in content and terminology, as well as with the acts regulating concessions and public procurement which are also applicable to the system of performance of public transport in coastal liner shipping. A significant number of definitions from the EU Acquis needed to be transposed into the $A c t$, increasing its scope. However, interventions into the text of the Act did not change its underlying concept. The procedure of selection of shipping companies for providers of public maritime liner transport, as a service of general economic interest, using the mechanism of public service contracts concluded on the basis of public invitations to tender open to all shipping companies from the European Economic Area, has become clearer and more precise.

While pursuant to the provisions contained in the previously applicable text of the Act, the right to perform maritime liner transport was obtained on the basis of a concession, new provisions of the Act stipulate that the right to perform public transport services, as services of general economic interest, may be obtained based either on a concession decision or a decision on the selection of the best tenderer, which then serve as the

19. With the adoption and entry into force of the Decision, the Decision on the establishment of state lines in public transport in coastal liner shipping, class: 342 01/08-01/05, reg. no. 5030116-08-1, of 5 December 2008, class: 342-01/1001/01, reg. no. 5030116-10-1, of 4 March 2010, class: 342-01/10-01/01, reg. no. 5030116-11-1, of 20 October 2011 and class: 022-03/13-04/47, reg. no. 5030105/20-13-4, of 11 April 2013. basis for the conclusion of concession contracts or contracts on public transport services, jointly referred to as public service contracts.

The Act now also separately regulates public liner shipping without public service obligation, with the aim of ensuring optimum traffic connections between the islands and the mainland under any conditions, while the privileged transport system is regulated in more detail both by the Act and sublegal regulations. Another positive novelty is the provision stipulating that the adoption of sailing schedules requires the prior approval of the proposed sailing schedules on state lines by executive bodies of local self-governing units, the competent harbor master's office and the competent port authority, while the Agency gives subsequent approval. It supplanted the inadequate provision of the previously applicable text of the Act which failed to specify the procedure for the adoption of sailing schedules, causing all sorts of issues in practice.

Although the deadline envisaged by the Act for the adoption, i.e. harmonization of sublegal regulations has elapsed, not all regulations have been adopted and harmonized. This is not the first time the ministry competent for maritime affairs is late and unsuccessful in the adoption of changes of implementing regulations within the legal deadline. The non-existence of a comprehensive legal framework introduces a certain level of legal insecurity, and since the market of public transport in coastal liner shipping is being fully opened up to European shipping companies, the ministry competent for maritime affairs is recommended to establish a comprehensive legal framework regulating this subject matter in the shortest period possible.

\section{REFERENCES}

Kavran, N., Bukljaš Skočibušić, M. and Stupalo, V., (2017), Okrugli stol - Budućnost linijskog pomorskog putničkog prometa u Republici Hrvatskoj, Proc. of Presentations, Zagreb, Croatia, April 5.

Mandić, N. and Amižić Jelovčić, P., (2014), Novine u Zakonu o prijevozu u linijskom i povremenom obalnom pomorskom prometu iz 2013. godine, Comparative Maritime Law, 53 (168), pp. 127-142.

Odluka o određivanju državnih linija u javnom prijevozu u linijskom obalnom pomorskom prometu, (2016), Croatian Goverment, Decision, Class 022-03/1604/363, no. 50301-25/14-16-2.

Pravilnik o uvjetima i načinu ostvarivanja prava na povlašteni prijevoz na linijama u javnom pomorskom prijevozu, (2017), Official Gazette, 2017(41).

Prijedlog Zakona o izmjenama i dopunama Zakona o prijevozu u linijskom i povremenom obalnom pomorskom prometu, s konačnim prijedlogom Zakona, (2016), Zagreb: Goverment of Republic of Croatia.

Zakon o prijevozu u linijskom i povremenom obalnom pomorskom prometu, (2006), Official Gazette, 2006(33), 2009(38), 2009(87), 2011(18), 2013(80) and 2016(56).

Agencije za obalni linijski pomorski promet, (2017), home page, available at: http:// www.agencija-zolpp.hr, [accessed 20 August 2017.]. 